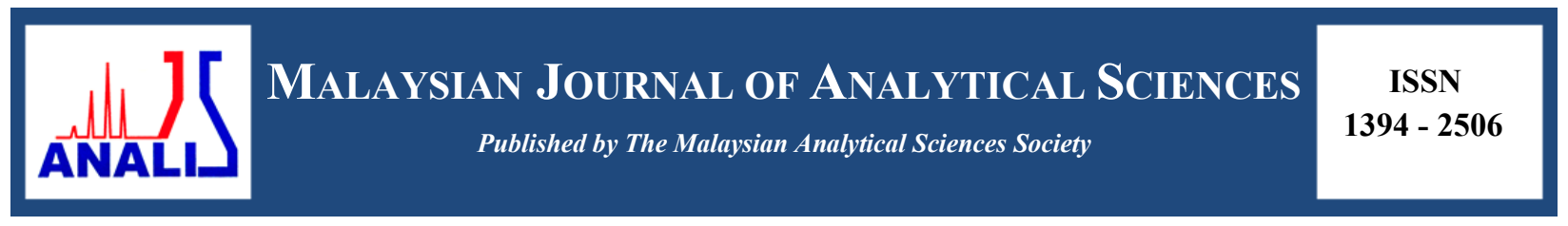

\title{
FLUORESCENCE QUENCHING ON MESOPOROUS CARBON NITRIDE BY PHENOL AND ANILINE
}

\author{
(Pelindapan Pendarfluor pada Karbon Nitrida Mesoliang oleh Fenol dan Anilina) \\ Leny Yuliati ${ }^{1,2,3 *}$, Ahmad Hanami Abd Kadir ${ }^{4}$, Siew Ling Lee ${ }^{3,4}$, Hendrik O. Lintang ${ }^{1,2,3}$ \\ ${ }^{1}$ Ma Chung Research Center for Photosynthetic Pigments \\ ${ }^{2}$ Department of Chemistry, Faculty of Science and Technology \\ Universitas Ma Chung, Villa Puncak Tidar N-01, Malang 65151, East Java, Indonesia \\ ${ }^{3}$ Centre for Sustainable Nanomaterials, Ibnu Sina Institute for Scientific and Industrial Research \\ ${ }^{4}$ Department of Chemistry, Faculty of Science \\ Universiti Teknologi Malaysia, 81310 UTM Johor Bahru, Johor, Malaysia \\ *Corresponding author: leny.yuliati@machung.ac.id
}

Received: 7 November 2016; Accepted: 18 September 2017

\begin{abstract}
In this study, fluorescence quenching on mesoporous carbon nitride (MCN) was examined in the presence of phenol and aniline. The MCN was synthesized by thermal polymerization of cyanamide using nanocolloidal silica (7 nm) as a hard template and characterized by X-ray diffractometer (XRD), Fourier transform infrared (FTIR), transmission electron microscope (TEM), specific surface area, pore size distribution, and fluorescence spectrophotometer. The MCN showed two excitation wavelengths at 275 and $370 \mathrm{~nm}$, owing to the presence of $\mathrm{N}=\mathrm{C}$ and $\mathrm{N}-\mathrm{C}$ terminal groups, respectively. These two excitation wavelengths gave only one emission peak at around $460 \mathrm{~nm}$. Either in the presence of phenol or aniline, the emission intensity of the MCN was confirmed to be quenched in a linear function towards the concentration of phenol or aniline as the quencher molecule. $\mathrm{N}-\mathrm{C}$ terminal groups were found to have slightly better interactions to phenol and aniline as compared to the $\mathrm{N}=\mathrm{C}$ groups. Since the emission intensity of MCN was more quenched by phenol molecules than the aniline, it was proposed that the MCN would have stronger interaction to phenol than aniline. This result was also supported by the adsorption data, in which the MCN gave higher adsorption towards phenol than the aniline.
\end{abstract}

Keywords: mesoporous carbon nitride, phenol, aniline, fluorescence quenching, adsorption

\begin{abstract}
Abstrak
Dalam kajian ini, pelindapan pendarfluor pada karbon nitrida mesoliang (MCN) telah diperiksa dengan kehadiran fenol dan anilina. MCN telah disintesis secara pempolimeran haba sianamida menggunakan silika nanokoloid (7 nm) sebagai templat keras dan telah dicirikan dengan pembelauan sinar-X (XRD), inframerah transformasi Fourier (FTIR), mikroskop elektron transmisi (TEM), luas permukaan, taburan saiz liang, dan spektroskopi pendafluor. MCN menunjukkan dua panjang gelombang pengujaan pada 275 dan $370 \mathrm{~nm}$ oleh kerana kehadiran masing - masing $\mathrm{N}=\mathrm{C}$ dan $\mathrm{N}-\mathrm{C}$ sebagai kumpulan terminal. Kedua-dua panjang gelombang pengujaan memberikan hanya satu puncak pelepasan pada kira-kira $460 \mathrm{~nm}$.Sama ada dengan kehadiran fenol atau anilina, keamatan pemancaran daripada MCN disahkan mengalami pelindapan dalam fungsi linear terhadap kepekatan fenol atau anilina sebagai molekul pelindap. Kumpulan terminal N-C didapati mempunyai interaksi lebih baik sedikit untuk fenol dan anilina berbanding dengan kumpulan $\mathrm{N}=\mathrm{C}$. Oleh kerana keamatan pemancaran $\mathrm{MCN}$ didapati lebih terlindap oleh molekul fenol berbanding dengan anilina, adalah dicadangkan bahawa MCN berinteraksi lebih kuat dengan fenol dibandingkan dengan anilina. Keputusan ini juga disokong oleh data penjerapan, dengan MCN memberikan penjerapan yang lebih tinggi terhadap fenol dibandingkan dengan anilina.
\end{abstract}

Kata kunci: karbon nitrida mesoliang, fenol, anilina, pelindapan pendarfluor, penjerapan 


\section{Introduction}

Carbon nitrides $(\mathrm{CN})$ are carbon materials in which some carbon atoms in the graphite-like structure are replaced by some nitrogen atoms in a regular manner. Generally, $\mathrm{CN}$ stands for a large family of related compounds $\left(\mathrm{C}_{\mathrm{x}} \mathrm{N}_{\mathrm{y}}\right)[1-$ 3]. Even though the $\mathrm{CN}$ has been reported since the $1990 \mathrm{~s}$, this material still receives considerable attention because of its versatility until nowadays. The $\mathrm{CN}$ is used in various applications while the material is just composed of $\mathrm{C}$, $\mathrm{N}$ and $\mathrm{H}$ atoms [4]. Other factors that make $\mathrm{CN}$ being well explored is because of the abundance of these atoms on earth, non-toxic and easy to be synthesized into a desired shape where the pore of carbon nitride is tunable to form mesoporous carbon nitride (MCN) $[1,5,6]$. MCN has a larger specific surface area than the $\mathrm{CN}$ and it facilitated better performance for various applications [7 - 12]. Moreover, $\mathrm{CN}$ has many advantageous properties that make it an interesting material, such as high thermal and chemical stability, and great optical properties [13 - 15].

Recently, application of $\mathrm{CN}$ and $\mathrm{MCN}$ as fluorescence sensor has been a significant interest. Owing to the presence of fluorescent active sites (tri-s-triazine units), $\mathrm{CN}$ and $\mathrm{MCN}$ are potential materials to be used as an optical sensor. Despite of the fact that these materials have a strong fluorescence property, less attention was paid on its sensing ability until there was a report showing the utilities of cubic MCN as all-in-one chemosensor for sensing of trace amount of metal ions in aqueous solution [16]. Since the cubic MCN has the highest sensitivity and selectivity towards copper ions, further modification was also carried out by the research group on the cubic MCN incorporating copper ions for sensing of cyanide ions, which are very poisonous and used abundantly in metal plating industry [17]. $\mathrm{CN}$ has been also reported as an efficient fluorosensor for detection of copper ions. It was suggested that the fluorescence quenching was due to strong coordination of the Lewis basic sites on the CN with the $\mathrm{Cu}$ ions [18]. Besides metal and cyanide ions, recent studies showed that nitrogen-containing compounds can be also detected by fluorescence quenching. It was reported that $\mathrm{MCN}$ was able to be used as a fluorescence sensor for $N$-nitrosopyrrolidone (NPYR) [7]. The surface interaction was proposed to involve electrostatic interactions between the electropositive $\mathrm{N}$ and electropositive $\mathrm{N}$ at the NPYR molecules and terminal $\mathrm{N}-\mathrm{C}$ groups of the MCN, respectively. $\mathrm{CN}$ was also reported as a fluorescence chemical sensor for nitrate ions [19].

In this study, fluorescence quenching on MCN was investigated in the presence of aromatic compounds, which are phenol and aniline. Phenol is considered as one of the organic pollutants that can be easily found in industrial wastewater [20 - 22]. The wastewater containing phenol may cause the contamination of groundwater and it will give bad effects for ecosystems and also for human. Meanwhile, aniline is also recognized as one of the high priority pollutants that are released from several industries, such as various manufacturers of dyes, and rubber, which caused wide distribution of aniline in the environment [23 - 25]. As an adsorbent, MCN possesses wellordered porosity, high surface area, and basic groups $\left(\mathrm{NH}\right.$ and $\left.\mathrm{NH}_{2}\right)$ in the structures, which are the important criteria for the removal of organic pollutants. Due to the nitrogen rich structure of MCN with basicity property, it showed remarkable adsorptions towards one of the acidic persistent organic pollutants, i.e. phenol [26]. On the other hand, the MCN was also reported showing superior capability to adsorb aniline than the CN and MCM-41 [8, 9]. Therefore, based on these reported studies, the fluorescence quenching on MCN by phenol and aniline is feasible. This study demonstrated that MCN can be also used as a fluorescence sensor for the aromatic compounds.

\section{Preparation of MCN}

\section{Materials and Methods}

The MCN was prepared by a thermal polymerization of cyanamide as the precursor, in the similar way to the method reported in other literatures [7 -9]. The cyanamide was mixed with the colloidal silica as a hard template 7 $\mathrm{nm}$ (mass ratio was 1:1), followed by stirring and heating at $363 \mathrm{~K}$ until a white powder was formed. The obtained white powder was ground and then heated at a temperature of $823 \mathrm{~K}$ for 4 hours. In order to obtain the MCN, the silica template was removed by treating the $\mathrm{MCN}$ powder with the $\mathrm{NH}_{4} \mathrm{HF}_{2}$ solution $(4 \mathrm{M}, 400 \mathrm{~mL})$ under vigorous stirring and also with ethanol and distilled water. This washing step was repeated for three times. After washing and filtration, the powder was dried at $343 \mathrm{~K}$ overnight in an oven.

\section{Characterizations}

The structure of the MCN was determined by an X-ray diffractometer (XRD) on a Bruker D8 Advance Diffractometer at ambient temperature, with a scan rate of $0.05 \mathrm{~s}^{-1}$ using $\mathrm{Cu}-\mathrm{K} \alpha$ radiation where $\lambda$ equals to 
$1.5406 \AA$ at $40 \mathrm{kV}$ and $40 \mathrm{~mA}$. To determine the structural information and functional groups of the MCN, a Fourier transform infrared spectroscopy (FTIR) was employed using a FTIR Nicolet iS50 Thermo Scientific. For pellet preparation, a small amount of the MCN was mixed with potassium bromide (KBr) and put under a pellet press. To obtain a better background correction, nitrogen gas was purged into the system before the analysis to remove all humidity. Morphology of the MCN was measured using a transmission electron microscope (TEM) on a JEOL JEM-2100. The MCN powder was first dispersed well in acetone, and then put onto the copper grid to be observed with the TEM. The surface area of the MCN was determined by using the Brunauer-Emmet-Teller (BET) equation, while the pore size of the MCN was determined using the Barret-Joyner-Halenda (BJH) from adsorption-desorption isotherm at $77 \mathrm{~K}$ obtained on a Quanta chrome Autosorb-1 instrument. The fluorescence properties were measured using a JASCO Spectrofluorometer FP-8500 to obtain the excitation and emission spectra. The excitation wavelengths used to monitor the emission spectra were 275 and $370 \mathrm{~nm}$, while the emission wavelength used to monitor the excitation spectra was $460 \mathrm{~nm}$. The analysis was carried out at room temperature.

\title{
Fluorescence quenching
}

The quenching tests were carried out with various concentrations of phenol and aniline on the MCN (50 mg) at room temperature. The excitation wavelengths at 275 and $370 \mathrm{~nm}$ of the $\mathrm{MCN}$ were determined by observing the emission spectrum at $460 \mathrm{~nm}$. Meanwhile, the emission wavelength was determined by observing excitation spectra at both excitation wavelengths. From various amounts of phenol solutions $(300-600 \mathrm{ppm}), 20 \mu \mathrm{L}$ of the solution was taken and then introduced onto the MCN for the quenching test for phenol. The changes in the emission spectra of the MCN were then measured at excitation wavelengths of 275 and $370 \mathrm{~nm}$. As for the quenching test for aniline, the same steps were followed using various concentrations of aniline solution $(200-700 \mathrm{ppm})$.

\begin{abstract}
Adsorption tests
The adsorption process of phenol or aniline onto the $\mathrm{MCN}$ was conducted under dark condition using various concentrations of phenol $(60-400 \mathrm{ppm})$ and aniline $(100-500 \mathrm{ppm})$ at room temperature. Different series of concentrations were selected due to the different behaviors of the observable adsorption. A magnetic bar was put in a $30 \mathrm{~mL}$ beaker and $10 \mathrm{~mL}$ of phenol or aniline solution was poured into the beaker together with the MCN (50 $\mathrm{mg}$ ). Inside a closed box, the beaker containing the mixture was placed on the stirring plate and stirred for 6 hours. After filtration and separation from the $\mathrm{MCN}$, the solution was analysed using gas chromatography with a flame ionization detector (GC-FID) on an Agilent 7820AGC-FID. The adsorbed amount was determined by subtracting the initial phenol or aniline with the amounts of remaining phenol or aniline after the adsorption test.
\end{abstract}

\section{Properties of MCN}

\section{Results and Discussion}

Shown in Figure 1(a) is the XRD pattern of the prepared MCN, which gave two diffraction peaks at $2 \theta$ of 13.1 and $27.4^{\circ}$. The peak at $2 \theta$ of $13.1^{\circ}$ was corresponding to the distance of $0.66 \mathrm{~nm}$, which indicated the in-planar repeating units and structural packing motif, such as hole-to-hole distance of the nitride pores, while the intense diffraction peak at the $2 \theta$ of $27.4^{\circ}$ could be indexed as (002) for graphitic materials, giving an interlayer distance of $0.325 \mathrm{~nm}$ for the graphite-like stacking of the conjugated aromatic $\mathrm{CN}$ layers. This result is in good agreement with values reported elsewhere $[4,7-11,13,14]$. Therefore, it can be concluded that the MCN sample was successfully synthesized.

The functional groups present on the MCN were investigated by FTIR spectroscopy. As shown in Figure 1(b), the absorption peaks of the MCN were observable at the region of $809,1200-1700$ and $3000-3700 \mathrm{~cm}^{-1}$. The bands at $809,1252,1319,1428$ and $1646 \mathrm{~cm}^{-1}$ could be attributed to the vibration modes of heterocyclic tri-s-triazine ring $\left(\mathrm{C}_{6} \mathrm{~N}_{7}\right)$ units, while the broad peak at $3163 \mathrm{~cm}^{-1}$ could be assigned to two overlapping bands of stretching modes of $\mathrm{N}-\mathrm{H}$ and $\mathrm{O}-\mathrm{H}$ groups $[9,11,27]$. The peak at $2177 \mathrm{~cm}^{-1}$ could be attributed to the presence of $\mathrm{C} \equiv \mathrm{N}$ or $\mathrm{N}=\mathrm{C}=\mathrm{N}$ group, which was reported in MCN prepared via thermal polymerization reaction [27]. These FTIR spectra supported that the MCN sample was successfully prepared. 


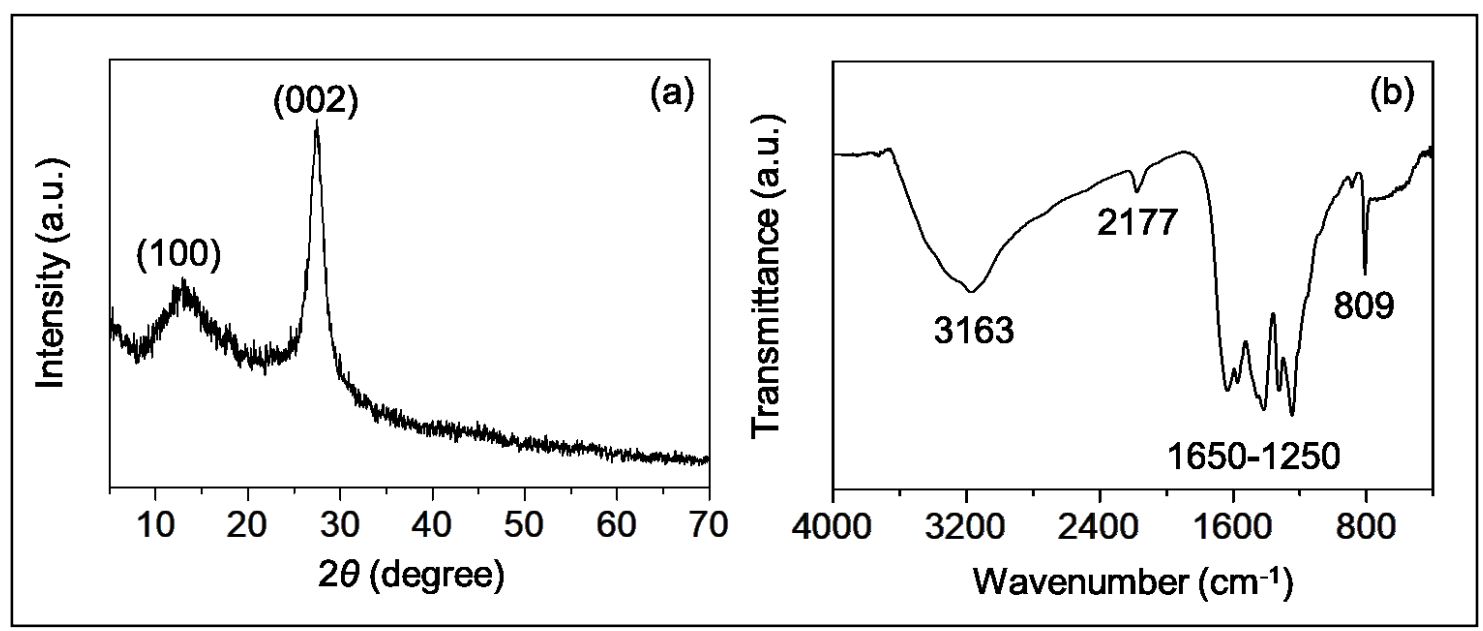

Figure 1. (a) XRD pattern and (b) FTIR spectrum of MCN

The morphology of the prepared MCN was observed by TEM as shown in Figure 2. It can be seen that the MCN has uneven layers due to the graphitic structures of the MCN. Figure 3(a) shows the nitrogen adsorption-desorption isotherms and Figure 3(b) shows the Barrett-Joyner-Halenda (BJH) pore size distribution of the MCN. The results suggested that the MCN has type IV isotherm for mesoporous material with hysteresis loop at relative pressure of $0.5-1$ due to the capillary condensation in pores. The BET specific surface area of the MCN was determined to be $287 \mathrm{~m}^{2} \mathrm{~g}^{-1}$. Meanwhile, for BJH pore size distribution, the MCN showed a narrow and sharp pore size of $7 \mathrm{~nm}$. This pore size reflected the size of the silica template that was used for the preparation of the MCN.
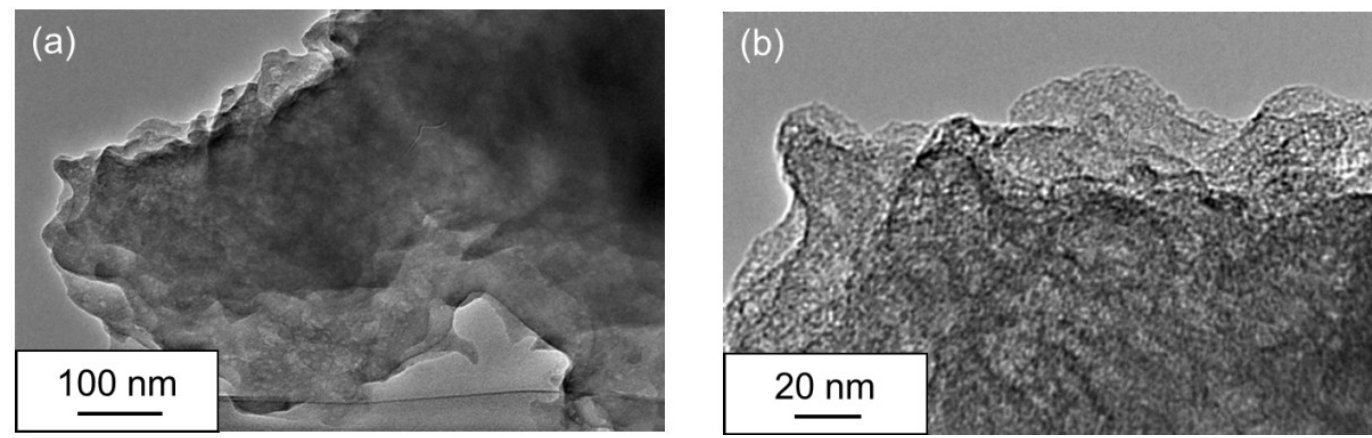

Figure 2. TEM images of MCN shown in different magnification scale bars, (a) $100 \mathrm{~nm}$ and (b) $20 \mathrm{~nm}$ 


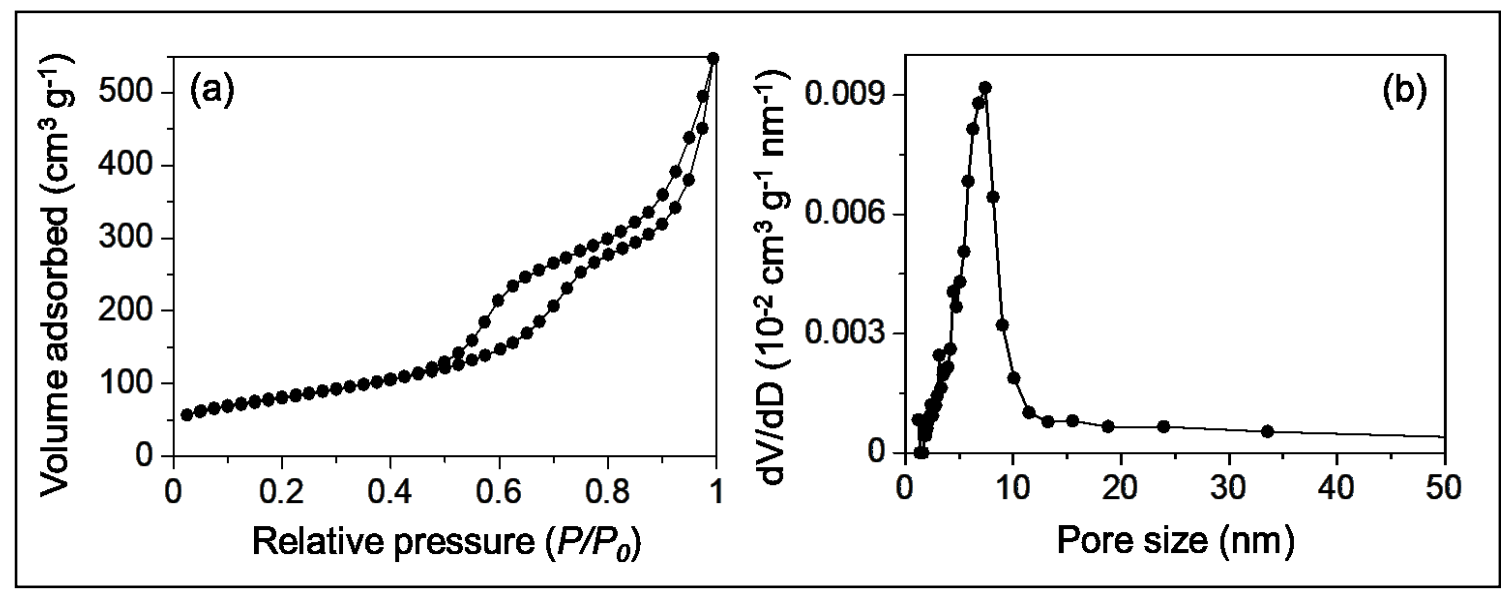

Figure 3. (a) Nitrogen adsorption-desorption isotherm and (b) BJH pore size distribution of MCN

Figure 4(a) displays the excitation spectrum of the MCN. It was clear that the MCN exhibited two excitation peaks at 275 and $370 \mathrm{~nm}$. The excitation peak at $275 \mathrm{~nm}$ can be attributed to the $\pi$ to $\pi^{*}$ electronic transition of the $\mathrm{N}=\mathrm{C}$ groups in the aromatic 1,3,5-triazine ring of MCN. Meanwhile, the other excitation peak at $370 \mathrm{~nm}$ can be attributed to $n$ to $\pi^{*}$ electronic transition of a terminal N-C group involving lone pairs of nitrogen atoms. As can be seen from Figure 4(b), the MCN gave one emission peak at a wavelength of $460 \mathrm{~nm}$ when the MCN was excited either at 275 or $370 \mathrm{~nm}$. These results agree well with previous reports [7, 9, 19].

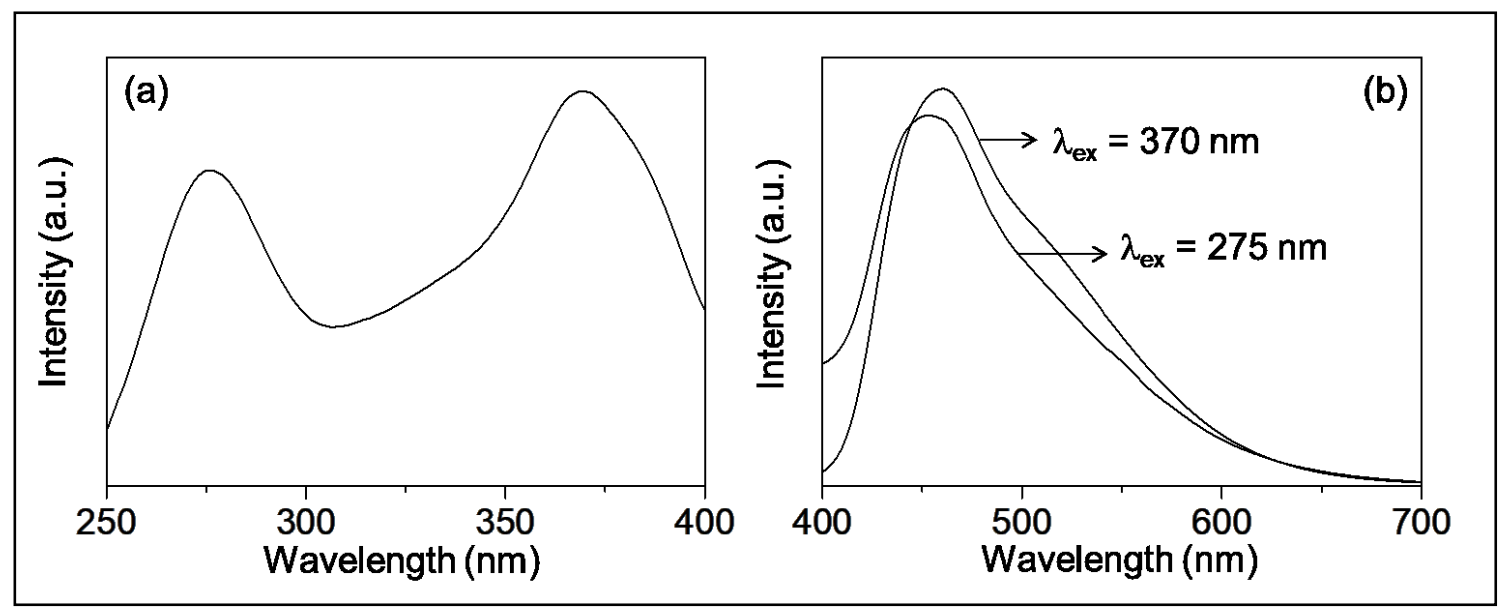

Figure 4. (a) Excitation and (b) emission spectra of MCN that were monitored at emission wavelength of $460 \mathrm{~nm}$ and excitation wavelengths of 275 and $370 \mathrm{~nm}$

\section{Fluorescence quenching}

Quenching tests were conducted on the MCN by the addition of various concentrations of phenol or aniline in order to investigate the sites where the interactions occurred either at $\mathrm{N}=\mathrm{C}$ groups or terminal $\mathrm{N}-\mathrm{C}$ groups. The quenching tests were determined by observing the changes in the emission intensity of the MCN sample before and after the addition of phenol or aniline. Since one emission spectrum at around $460 \mathrm{~nm}$ was observed for both excitations at 275 and $370 \mathrm{~nm}$, the quenching tests were carried out by monitoring the intensity of the emission peak at $460 \mathrm{~nm}$ excited at both excitation wavelengths. As illustrated in Figure 5(a) and (b), the emission intensities of the MCN 
excited at both excitation wavelengths of 275 and $370 \mathrm{~nm}(\mathrm{~N}=\mathrm{C}$ and terminal N-C emission sites), respectively decreased with the addition of the phenol. This result showed that phenol acted as a quenching agent to deactivate the emission sites. When the added phenol concentration increased, the emission intensity was further decreased. The decrease in the emission intensity would be due to the interactions between the emission sites of MCN at an emission wavelength of $460 \mathrm{~nm}$ and the added phenol.

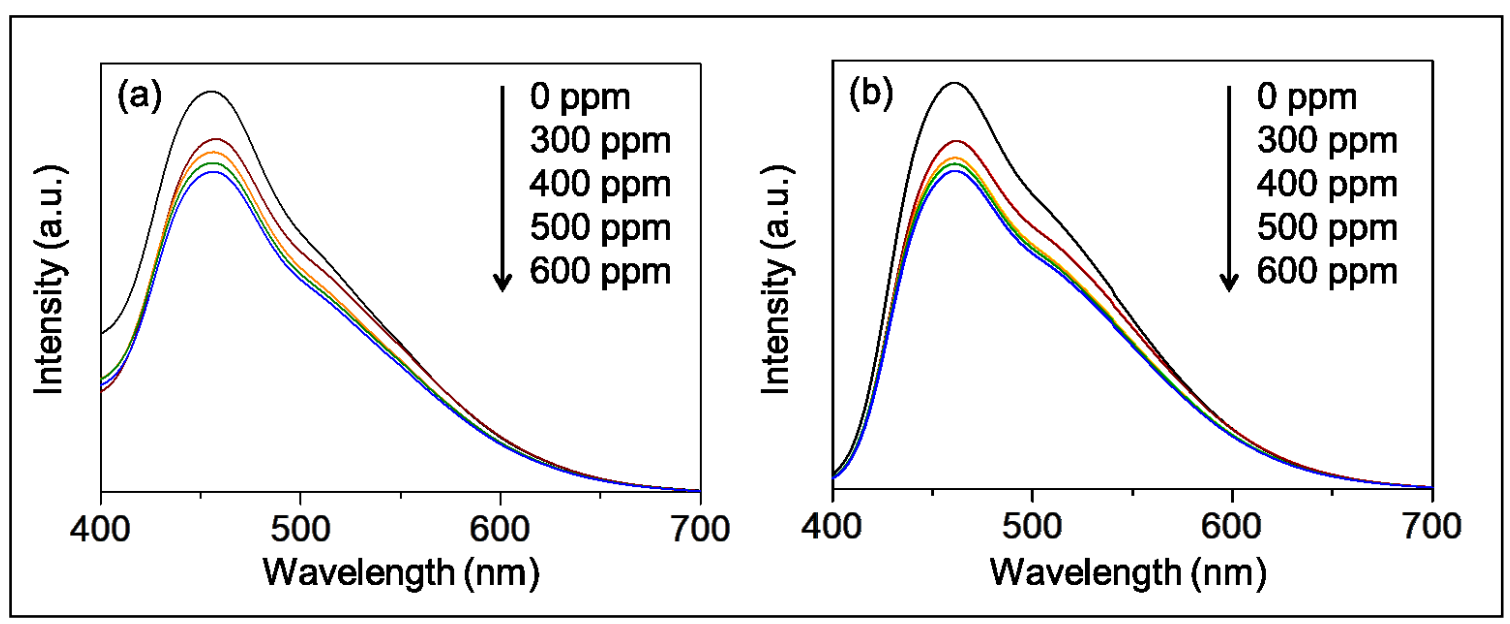

Figure 5. Fluorescence quenching on $\mathrm{MCN}$ in the absence and presence of phenol (0-600 ppm) when excited at (a) $\mathrm{N}=\mathrm{C}$ and (b) terminal $\mathrm{N}-\mathrm{C}$ groups

In order to have a better understanding about the interaction of $\mathrm{MCN}$ with phenol, the quenching results were plotted according to the Stern-Volmer plot following the equation 1:

$$
I o / I=K_{S V}[Q]+1
$$

where $I o$ and $I$ are fluorescence intensities observed in the absence and presence of phenol, $Q$ is the concentration of phenol, and $K_{S V}$ is the Stern-Volmer quenching constant.

Based on the Stern-Volmer equation, the relative emission intensity would be expressed as the function of phenol concentration when the same amount of $\mathrm{MCN}$ and the constant illumination intensity were taken in account. Figure 6 shows the Stern-Volmer plots of the relative emission intensity of MCN with various concentrations of phenol. In the range of $300-600 \mathrm{ppm}$, the relative emission intensity excited at both emission sites gave a linear Stern-Volmer plot with the concentrations of phenol. The linear Stern-Volmer plot indicated that the MCN could detect phenol using the fluorescence spectroscopy. Meanwhile, the quenching efficiency of phenol on the emission site of MCN could be obtained from the slope of the linear plot, which was matched to the quenching rate constant ( $K_{S V}$ value). It was shown that the $K_{S V}$ values for the emission sites monitored at excitation wavelengths of 275 and $370 \mathrm{~nm}$ were $4 \times 10^{-4}$ and $5 \times 10^{-4} \mathrm{ppm}^{-1}$, respectively. These results suggested that the emission sites of MCN excited at 275 and $370 \mathrm{~nm}$ have almost equal interactions with phenol, which the terminal N-C groups gave slightly better interaction than the $\mathrm{N}=\mathrm{C}$ groups.

Figure 7(a) and (b) show the changes on the emission intensities excited at 275 and $375 \mathrm{~nm}$, respectively in the presence of aniline. Similar to the phenol addition, the addition of aniline quenched the intensity of the MCN. Aniline also acted as a quenching agent that deactivated the emission sites of MCN. When the concentration of aniline increased, the emission intensity was also further reduced. The decrease in the emission intensity of the $\mathrm{MCN}$ suggested that there were interactions between the $\mathrm{N}=\mathrm{C}$ and terminal $\mathrm{N}-\mathrm{C}$ emission sites and the aniline. As previously mentioned, the $\mathrm{MCN}$ has two excitation sites at 275 and $370 \mathrm{~nm}$, which belong to the $\mathrm{N}=\mathrm{C}$ groups 
$\left(\pi-\pi^{*}\right)$ in the aromatic 1,3,5-triazine and the terminal N-C groups $\left(n-\pi^{*}\right)$, respectively. In order to investigate which sites were favoured to the aniline, the Stern-Volmer plot was performed.

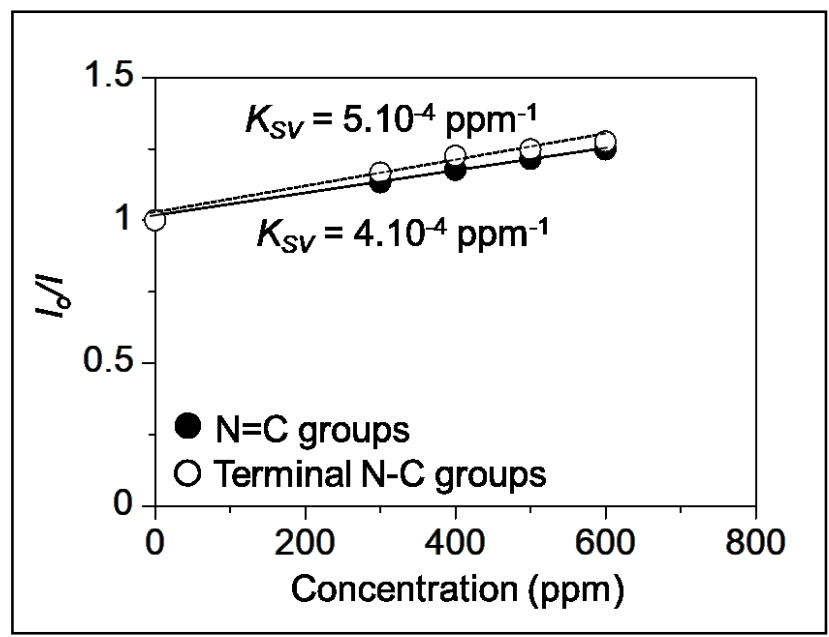

Figure 6. Stern Volmer plots of phenol quenching on $\mathrm{MCN}$ at $\mathrm{N}=\mathrm{C}$ and terminal $\mathrm{N}-\mathrm{C}$ groups

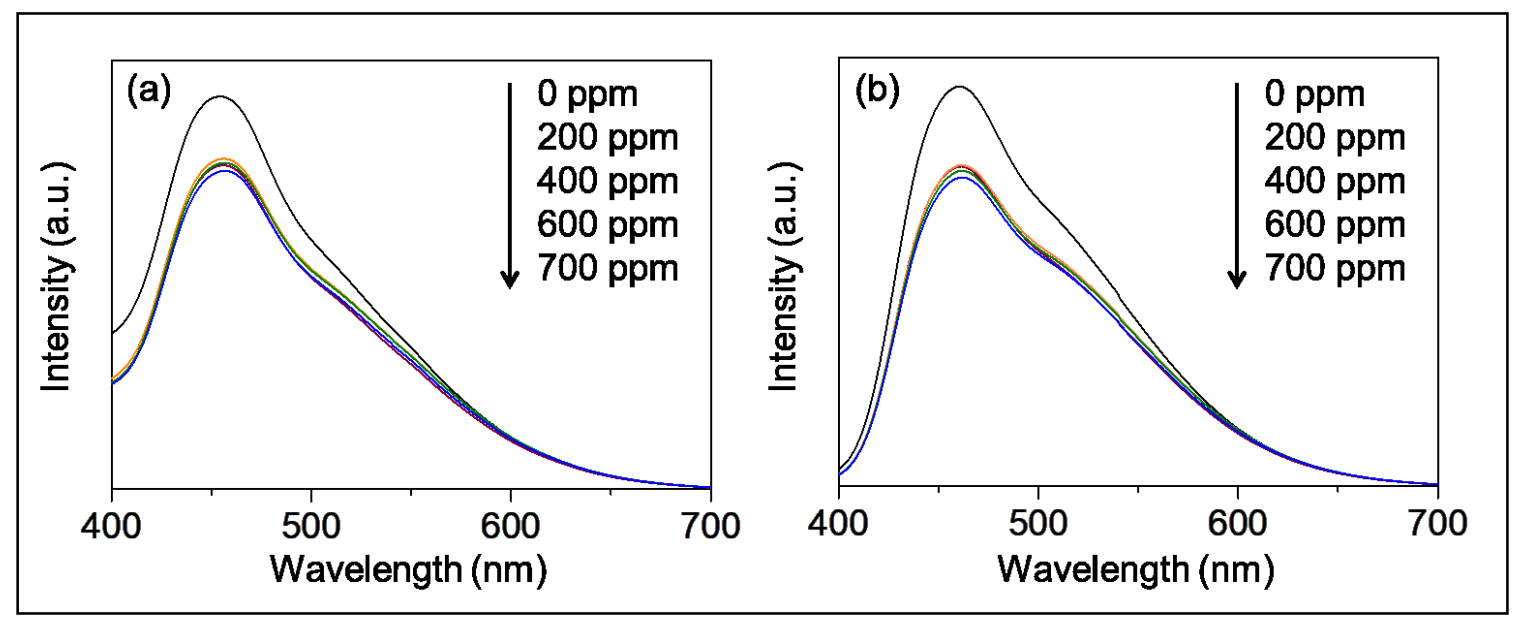

Figure 7. Fluorescence quenching on $\mathrm{MCN}$ in the absence and presence of aniline $(0-700 \mathrm{ppm})$ when excited at (a) $\mathrm{N}=\mathrm{C}$ and (b) terminal $\mathrm{N}-\mathrm{C}$ groups

Shown in Figure 8 is the linear Stern-Volmer plots between the relative emission intensity of MCN with various concentrations of aniline in the range of $200-700 \mathrm{ppm}$. Both emission sites, the $\mathrm{N}=\mathrm{C}$ and terminal $\mathrm{N}-\mathrm{C}$ groups showed the linear Stern-Volmer plots with the addition of aniline. $K_{S V}$ values obtained were $3 \times 10^{-4}$ and $4 \times 10^{-4}$ $\mathrm{ppm}^{-1}$ for the $\mathrm{N}=\mathrm{C}$ and terminal $\mathrm{N}-\mathrm{C}$ groups, respectively. The slightly higher $K_{S V}$ value of the terminal N-C group suggested that similar to the results when using phenol as the quencher agent, aniline also favored the terminal N-C groups. Based on the fluorescence quenching tests, it was demonstrated that the MCN showed good interactions with phenol and aniline. 


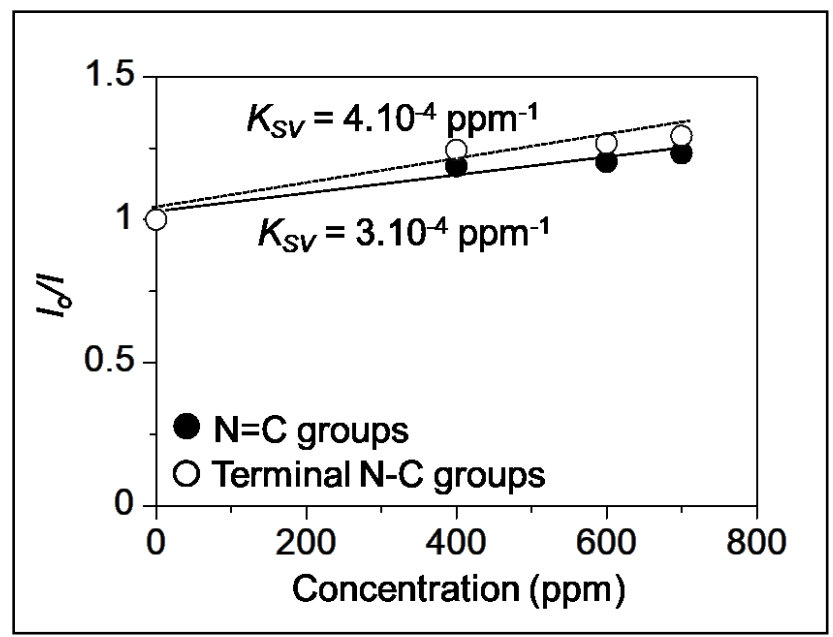

Figure 8. Stern Volmer plots of aniline quenching on $\mathrm{MCN}$ at $\mathrm{N}=\mathrm{C}$ and terminal $\mathrm{N}-\mathrm{C}$ groups

\section{Adsorption tests}

Adsorption capability of the MCN towards phenol or aniline was examined by using different concentrations. The adsorption test for phenol was carried out at room temperature with the concentration of phenol was varied from 60 to $400 \mathrm{ppm}$. Figure 9 presents the results of the adsorption test of phenol on the MCN. The amount of adsorbed phenol increased with the increase of the phenol concentration when it was below $100 \mathrm{ppm}$. Further increase of the phenol concentration at more than $100 \mathrm{ppm}$ did not affect much the amount of adsorbed phenol. Figure 9 also shows the results of aniline adsorption on the MCN with various concentrations from 100 to $500 \mathrm{ppm}$. Separated experiments confirmed that no aniline adsorption occurred when the aniline concentration was lower than $100 \mathrm{ppm}$. At concentration of $100 \mathrm{ppm}$ and above, the MCN showed an increased amount of adsorption with the increase of aniline concentration up to $500 \mathrm{ppm}$. Compared to the adsorption of phenol, higher amount of aniline was required for MCN to act as an adsorbent.

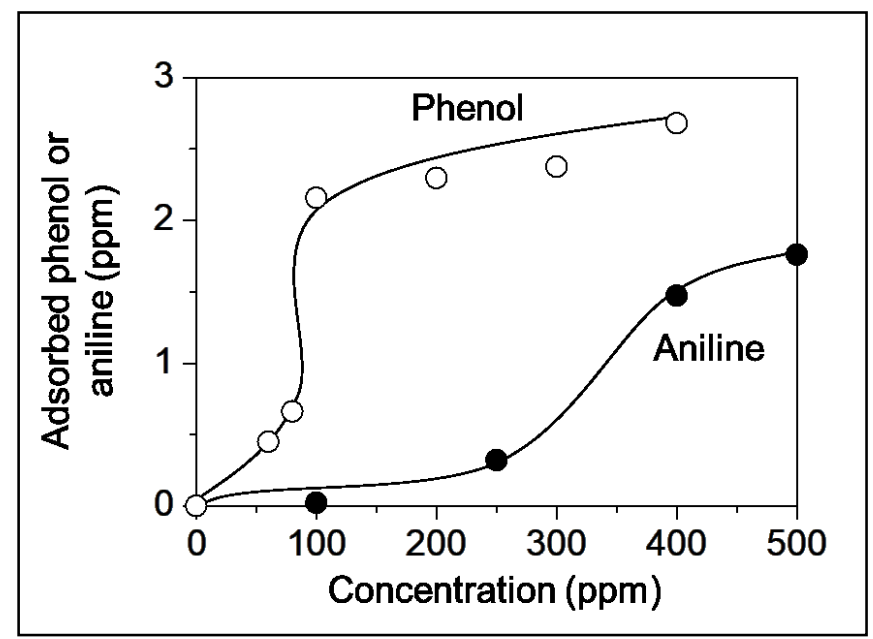

Figure 9. Adsorption of phenol and aniline with various concentrations on $\mathrm{MCN}$ at room temperature

From the adsorption test analyses, it can be proposed that phenol and aniline were successfully adsorbed on the MCN. However, under the same concentration for instance at $100 \mathrm{ppm}$, the MCN gave better adsorption towards phenol than the aniline, which gave adsorbed amounts of 2.16 and $0.02 \mathrm{ppm}$, respectively. The higher adsorbed 
amount of phenol than aniline might be due to the fact that phenol is a weak acid, while aniline is a weak base. Therefore, basicity of the MCN would favor phenol rather than aniline. It can be proposed that phenol would give stronger interaction to the $\mathrm{MCN}$, which in turn gave higher $K_{S V}$ value than the aniline. As has been reported elsewhere [7], the presence of electronegative $\mathrm{N}$ at the terminal $\mathrm{N}-\mathrm{C}$ groups of the $\mathrm{MCN}$ provided the possibility for the formation of electrostatic interactions towards the analyte molecules. As phenol is a weak acid, the acid-base electrostatic interactions would occur between the electronegative $\mathrm{N}$ at the terminal $\mathrm{N}-\mathrm{C}$ groups of the $\mathrm{MCN}$ and the electropositive phenolic proton. As for aniline, the electrostatic interactions would occur between the electronegative $\mathrm{N}$ at the terminal $\mathrm{N}-\mathrm{C}$ groups of the $\mathrm{MCN}$ and the electropositive $\mathrm{H}$ at the $\mathrm{NH}_{2}$ group of the aniline, which was less electropositive than the phenolic proton.

\section{Conclusion}

Characterizations by XRD, FTIR, TEM, surface area and pore size analyzer, and fluorescence spectroscopy confirmed that the MCN was prepared successfully by thermal polymerization of cyanamide using nanocolloidal silica as the hard template. The MCN was shown to have good interactions with phenol and aniline, where its emission intensity was quenched almost linearly with the addition of these aromatic compounds. It was obtained that the terminal $\mathrm{N}-\mathrm{C}$ groups gave slightly higher quenching efficiency than the $\mathrm{N}=\mathrm{C}$ groups for both phenol and aniline. Phenol gave better interactions towards the emission sites of the MCN, owing to the stronger adsorption of phenol on to the MCN than the aniline caused by the acid-base electrostatic attractive force.

\section{Acknowledgement}

This work was financially supported by the Ministry of Higher Education (MOHE, Malaysia) and the Universiti Teknologi Malaysia (UTM, Malaysia) through Flagship Research University Grant (cost center code: Q.J130000.2426.00G07).

\section{References}

1. Vinu, A. (2008). Two-dimensional hexagonally-ordered mesoporous carbon nitrides with tunable pore diameter , surface area and nitrogen content. Advanced Functional Materials, 18(5): 816 - 827.

2. Teter, D. M. and Hemley R. J. (1996). Low-compressibility carbon nitride. Science, 271(5245): 53 - 55.

3. Corkill, J. L. and Cohen, M. L. (1993). Calculated quasiparticle band gap of $\beta-\mathrm{C}_{3} \mathrm{~N}_{4}$. Physical Review B, 48(23): $17622-17624$.

4. Goettmann, F., Fischer, A., Antonietti, M. and Thomas, A. (2006). Chemical synthesis of mesoporous carbon nitrides using hard templates and their use as a metal-free catalyst for Friedel-Craft reaction of benzene. Angewandte Chemie International Edition, 45(27): 4467 - 4471.

5. Gillan, E. G. (2000). Synthesis of nitrogen-rich carbon nitride networks from an energetic molecular azide precursor. Chemistry of Materials, 12(12): 3906 - 3912.

6. Komatsu, T. (2001). Attempted chemical synthesis of graphite-like carbon nitride. Journal of Materials Chemistry, 11: $799-801$.

7. Sam, M. S., Lintang, H. O., Sanagi, M. M., Lee, S. L. and Yuliati, L. (2014). Mesoporous carbon nitride for adsorption and fluorescence sensor of N-nitrosopyrrolidine. Spectrochimica Acta Part A: Molecular and Biomolecular Spectroscopy, 124: 357 - 364.

8. Sam, M. S., Lintang, H. O., Sanagi, M. M., Lee, S. L. and Yuliati, L. (2014). Adsorption of aniline using novel mesoporous carbon nitride. Advanced Materials Research, 95: 135-139.

9. Sam, M. S., Tiong, P., Lintang, H. O., Sanagi, M. M., Lee, S. L. and Yuliati, L. (2015). Mesoporous carbon nitride as a metal-free catalyst for the removal of aniline. RSC Advances, 5: $44578-44586$.

10. Lee, S.C., Lintang, H.O. and Yuliati, L. (2012). A urea precursor to synthesize carbon nitride with meso porosity for enhanced activity in the photocatalytic removal of phenol. Chemistry An Asian Journal, 7(9): 2139 -2144 .

11. Cui, Y., Zhang, J., Zhang, G., Huang, J., Liu, P., Antonietti, M. and Wang X. (2011). Synthesis of bulk and nanoporous carbon nitride polymers from ammonium thiocyanate for photocatalytic hydrogen evolution. Journal of Materials Chemistry, 21: 13032 - 13039.

12. Wang, X., Maeda, K., Chen, X., Takanabe, K., Domen, K., Hou, Y., Fu, X. and Antonietti, M. (2009). Polymer semiconductors for artificial photosynthesis: hydrogen evolution by mesoporous graphitic carbon nitride with visible light. Journal of the American Chemical Society, 131(5): 1680 - 1681. 
13. Wang, Y., Wang, X. and Antonietti, M. (2012). Polymeric graphitic carbon nitrides as a heterogeneous organocatalyst: from photochemistry to multipurpose catalysis to sustainable chemistry. Angewandte Chemie International Edition, 51(1): 68 - 89.

14. Thomas, A., Fischer, A., Goettmann, F., Antonietti, M., Müller, J.-O., Schlögl, R. and Carlsson, J. M. (2008). Graphitic carbon nitride materials: Variation of structure and morphology and their use as metal-free catalyst. Journal of Materials Chemistry, 18(41): 4893 - 4908.

15. Zhang, Y., Mori, T. and Ye, J. (2012). Polymeric carbon nitrides: Semiconducting properties and emerging applications in photocatalysis and photoelectrochemical energy conversion. Science of Advanced Materials, 4(2): $282-291$.

16. Lee, E. Z., Jun, Y. S., Hong, W. H., Thomas, A. and Jin, M. M. (2010). Cubic mesoporous graphitic carbon(IV) nitride: an all-in-one chemosensor for selective optical sensing of metal ions. Angewandte Chemie International Edition, 49 (50): 9706 - 9710.

17. Lee, E. Z., Lee, S. U., Heo, N. S., Stucky, G. D., Jun, Y. S. and Hong, W. H. (2012). A fluorescent sensor for selective detection of cyanide using mesoporous graphitic carbon(IV) nitride. Chemical Communications, 48(33): $3942-3944$.

18. Tian, J., Liu, Q., Asiri, A. M., Al Youbi, A. O. and Sun, X. (2013). Ultrathin graphitic carbon nitride nanosheet: a highly efficient fluorosensor for rapid, ultrasensitive detection of $\mathrm{Cu}^{2+}$. Analytical Chemistry, 85(11): 5595 5599.

19. Alim, N. S., Lintang, H. O. and Yuliati, L. (2015). Fabricated metal-free carbon nitride characterizations for fluorescence chemical sensor of nitrate ions. Jurnal Teknologi, 76(13): $1-6$.

20. Dąbrowski, A., Podkościelny, P., Hubicki, Z. and Barczak, M. (2005). Adsorption of phenolic compounds by activated carbon - A critical review. Chemosphere, 58(8): 1049 - 1070.

21. Busca, G., Berardinelli, S., Resini, C. and Arrighi, L. (2008). Technologies for the removal of phenol from fluid streams: A short review of recent developments. Journal of Hazardous Materials, 160(2-3): 265 - 288.

22. Ahmed, S., Rasul, M. G., Martens, W. N., Brown, R. and Hashib, M.A. (2010). Heterogeneous photocatalytic degradation of phenols in wastewater: a review on current status and developments. Desalination, 261(1-2): $3-18$.

23. Soares, B. G., Amorim, G. S., Souza Jr, F. G., Oliveira M. G. and da Silva, J. E. P. (2006). The in situ polymerization of aniline in nitrile rubber. Synthetic Metals, 156 (2-4): $91-98$.

24. Zhao, R., Tan, C., Xie, Y., Gao, C., Liu, H. and Jiang, Y. (2011). One step synthesis of azo compounds from nitroaromatics and anilines, Tetrahedron Letter, 52(29): 3805 - 3809.

25. Puig, A., Ormad, P., Roche, P., Sarasa, J., Gimeno, E. and Ovelleiro, J. L. (1996). Wastewater from the manufacture of rubber vulcanization accelerators: Characterization, downstream monitoring and chemical treatment. Journal of Chromatography A, 733 (1-2): $511-522$.

26. Haque, E., Jun, J. W., Talapaneni, S. N., Vinu, A. and Jhung, S. H. (2010). Superior adsorption capacity of mesoporous carbon nitride with basic CN framework for phenol. Journal of Materials Chemistry, 20(48): $10801-10803$.

27. Miller, D. R., Wang, J. and Gillan, E. G. (2002). Rapid, facile synthesis of nitrogen-rich carbon nitride powders. Journals of Materials Chemistry, 12(8): 2463 - 2469. 